9-11-2014

\title{
The Influence of Board Diversity, Board Diversity Policies and Practices, and Board Inclusion Behaviors on Nonprofit Governance Practices
}

Kathleen Buse

Ruth Sessler Bernstein

University of Washington Tacoma, bernstrs@uw.edu

Diana Bilimoria

Follow this and additional works at: https://digitalcommons.tacoma.uw.edu/ias_pub

\section{Recommended Citation}

Buse, Kathleen; Bernstein, Ruth Sessler; and Bilimoria, Diana, "The Influence of Board Diversity, Board Diversity Policies and Practices, and Board Inclusion Behaviors on Nonprofit Governance Practices" (2014). SIAS Faculty Publications. 644.

https://digitalcommons.tacoma.uw.edu/ias_pub/644 
The Influence of Board Diversity, Board Diversity Policies and Practices, and Board Inclusion Behaviors on Nonprofit Governance Practices

Ruth Sessler Bernstein*

School of Business

Pacific Lutheran University

Tacoma, WA

bernstrs@plu.edu

Kathleen Buse

Weatherhead School of Management

Case Western University

Cleveland, $\mathrm{OH}$

Krb50@case.edu

Diana Bilimoria

KeyBank Professor

Professor and Chair of Organizational Behavior

Weatherhead School of Management

Case Western Reserve University

Cleveland, Ohio

diana.bilimoria@case.edu

*contact author 


\title{
The Influence of Board Diversity, Board Diversity Policies and Practices, and Board Inclusion Behaviors on Nonprofit Governance Practices
}

\begin{abstract}
This study examines how and when non-profit board performance is impacted by board diversity. Specifically, we investigate board diversity policies and practices as well as board inclusion behaviors as mediating mechanisms for the influence of age, gender and racial/ethnic diversity of the board on effective board governance practices. The empirical analysis, using a sample of 1456 nonprofit board chief executive officers, finds that board governance practices are directly influenced by the gender and racial diversity of the board and that board inclusion behaviors together with diversity policies and practices mediate the influence of the board's gender and racial diversity on internal and external governance practices. Additionally we found an interaction effect that indicates when boards have greater gender diversity, the negative impact of racial diversity on governance practices is mitigated. The findings suggest that board governance can be improved with more diverse membership but only if the board behaves inclusively and there are policies and practices in place to allow the diverse members to have an impact.
\end{abstract}

Key Words: Diversity, Diversity Policies and Practices, Inclusion Behavior, Board Effectiveness, Nonprofit Boards

The Authors thank BoardSource for providing the BoardSource Nonprofit Government Index and the two anonymous reviewers for their suggestions to improve the manuscript. 
The relationship between boardroom diversity and board performance continues to be of great interest to scholars, policy makers and practitioners alike. In the present study we empirically examine the relationship between board (age, gender and racial/ethnic) diversity and board performance outcomes in a sample of 1456 nonprofit organizations. We test the mediating effects of board diversity policies and procedures as well as board inclusion behaviors on this relationship, seeking to answer the question: How and when can board diversity enable effective governance practices?

It is commonly held that there is inherent value in diversity; that diverse groups, as compared with homogeneous groups, provide a broader range of information, knowledge, and perspectives (Cox et al., 1991; Ely and Thomas, 2001). But empirically, the benefits of diversity are complex to ascertain. Scholarly research on diversity in the workplace remains an enigma, sometimes supporting and sometimes undermining performance outcomes (Horwitz and Horwitz, 2007; Jehn and Bezrukova, 2004; Joshi and Roh, 2009; Milliken and Martins, 1996; Pitts, 2006; Ugboro and Obeng, 2009; van Knippenberg and Schippers, 2007; Williams and O’Reilly, 1998). Kochan et al. (2003) found racial and gender diversity to have neither a positive nor a negative effect on performance or group processes. Williams and O'Reilly (1998) analyzed 40 years of diversity research and concluded that many of these inconsistent results might be attributed to an oversimplified approach to diversity.

Horwitz and Horwitz's (2007) meta-analytic review of group-level diversity on outcomes and performance found that varying team member characteristics, such as age, ethnicity, and expertise, are negatively associated with performance outcomes (Jackson et al., 1995; Milliken and Martins, 1996). However, task-related diversity positively impacted the quality and quantity of team performance. Horwitz and Horwitz, therefore, recommend that high-performing teams 
be created with members who have task-relevant heterogeneity, instead of bio-demographic attributes. Joshi and Roh's (2009) meta-analytic review noted that the majority of studies investigating the relationship between diversity and group outcomes yielded "non-significant, direct relationships between team diversity and performance" (p. 599). Within these studies, the authors found that "approximately $60 \%$ of the direct effects reported... were non-significant for various attributes. Among the remainder, 20 percent of the effects reported were significantly positive, and 20 percent were significantly negative" (p.601). Suboptimal performance in diverse teams is associated with negative outcomes, including decreased cohesion, commitment and performance (Jehn et al., 1999) and may occur when the work context enhances stereotypes and biases toward minority groups and, also, where others perceive teams with higher representatives of minority groups of subpar performance (Joshi and Roh, 2009). More recently Hafsi \& Turgut (2013) determined empirically that diversity in boards, specifically gender (positively) and age (negatively), impact corporate social performance (related to corporate social responsibility). Projected demographic changes predict that the majority of the U.S. workforce will be composed of nonwhite, race-based minorities, including Hispanics, African Americans, and Asians, by 2039 (Treuhaft et al., 2011), however little has been accomplished in diversifying the boardroom in either the for-profit or nonprofit sectors. Caucasian men held $73 \%$ of board seats in the Fortune 500 companies in 2012, while minority men held 10\%, Caucasian women held $13 \%$, and only $3 \%$ of board seats were held by minority women (Alliance for Board Diversity, 2013). On the nonprofit board side, $82 \%$ of board members are Caucasian and this has not changed in the last two decades (Board Source, 2012). 57\% of nonprofit board members are men, and 59\% are over the age of 50 (Board Source, 2012). Only 23\% of nonprofit chief executives report satisfaction with the diversity of their boards (Board Source, 2012). 
Diversity within nonprofit boards holds potential for insuring that organizational programs and services reflect the needs and interests of the community, for bringing multiple perspectives into boardrooms that promote a culture of inquiry and generative thinking, and for breaking the cycle of power and privilege in the United States (Carter et al., 2003; Erhardt et al., 2003; Ferreira, 2010; Miller and Triana, 2009). However, in practice, such transformational aspects of diversification have eluded most nonprofit boards of directors (Bradshaw and Fredette, 2011). In light of these varied studies, further examination of nonprofit board diversity and governance practices is justified so as to enable board representation that is equivalent or at least similar to the organization's stakeholders.

Concepts and terminology from diversity literature as well as that on board practices are used in this empirical study. Here we define the terms used, starting with Cornforth's (2012) definition of governance as the "systems and processes concerned with ensuring the overall direction, control, and accountability of the organization" (p. 1121). Governance practices are those essential duties, functions, and competencies related to this direction, control and accountability (Fredette and Bradshaw, 2010). Board diversity policies and practices are those procedures adopted by boards with the intent to promote diversity. Board diversity policies and practices describe "practices and procedures that are commonly believed to enhance diversity and improve the experience for minority group members, such as diversity statements, policies, committees or taskforces dedicated to diversity and inclusion, diversity training for board members, and integration of diversity into the core mission and values" (Bernstein and Bilimoria, 2013, p. 641). Board inclusion behaviors are the actions of board members that enable members from minority and marginalized communities to feel respected and engaged in the organization's governance (Fredette and Bradshaw, 2010). These behaviors include "the 
intragroup communication, influence and power interactions that the dominant members of small groups engage in consciously or unconsciously which signal the authentic inclusion of diversity" (Bernstein and Bilimoria, 2013, p. 640).

In the present study, we hypothesize that board diversity policies and practices as well as board inclusion behaviors are influenced by the board's diversity and will mediate the effects of diversity on governance practices. Because previous studies have shown mixed results on the impact of diversity, we have chosen to examine the impact of mediating mechanisms as well as interaction effects related to gender, age and racial/ethnic diversity. We hypothesize a model that includes diversity policies and practices as well as inclusion behaviors to explain how diversity impacts board performance of internal and external governance. Figure 1 displays the hypothesized model where board diversity is linked to governance practices through diversity policies and practices as well as inclusion behaviors.

Insert Figure 1 about here

\section{Theory Development and Hypotheses}

Governance practices are measures of board effectiveness as these practices reflect the board's capacity to perform various functions and competencies (Fredette and Bradshaw, 2010). They pertain to how competently board members perform essential governance duties and functions. A variety of strategies have been suggested in the literature for assessing the performance of the board on essential practices (Bradshaw et al., 1992; Callen et al., 2010; Chait, Holland, and Taylor, 1991; Cornforth, 2001; Green and Griesinger, 1996; Herman and Renz, 1998; Herman et al., 1996; Jackson and Holland, 1998, Nobbie and Brudney, 2003). Internal practices represent work undertaken by board members within the boardroom or organization 
while external practices occur outside the boardroom or organization. The assessment of the board's performance of internal practices includes strategic planning, legal, ethical, and financial oversight, evaluating, guiding, and supporting the CEO, monitoring performance, understanding the board's roles and responsibilities, and include the board's level of commitment and involvement. The assessment of the board's performance of external practices includes fundraising, community relations and outreach, and recruiting new board members.

Board composition studies have generally focused on examining the relationship between board diversity and performance, on the assumption that who serves on the board has an impact on board outcomes (Brown, 2002; Bradshaw et al., 1996; Duca, 1996; Gitin, 2001; Siciliano, 1996; Stone and Ostrower, 2007). However, some studies assessing the impact of diversity on governance practices in a range of contexts collectively have resulted in mixed findings, often attributed to the complexity of the relationships between diversity and performance. For example, Siciliano (1996) found that age diversity in board members was linked to higher levels of donations, but was insignificant with respect to the organization's social performance. The same study suggested that gender diversity had a positive impact on the organization's social performance, but a negative impact on fundraising. Subsequent studies of for-profit firms have demonstrated that gender and age diversity have a significant impact on corporate social performance (Boulouta, 2013; Hafsi and Turgut, 2013; Zhang et al, 2013). Several studies show that increased gender board diversity generates economic gains, resulting in a positive impact on financial performance and firm value (Campbell and Mínguez-Vera, 2008; Francoeur et al, 2008). Other studies show that gender board diversity impacts other factors important to organizations including the extent of diversity in the top management team (Bilimoria, 2000; 2006). Bernstein and Davidson (2012) found that racial/ethnic diversity had an impact on 
nonprofit board performance when inclusion behavior was used as a mediator. In the corporate boardroom, racial and gender diversity have been shown to positively influence firm performance (Carter et al., 2003; Erhart et al., 2003).

Applying the rationale that diverse membership provides a broader range of knowledge, information, and perspectives, we hypothesize that board member demographic diversity (gender, age, and race/ethnicity) will have a positive and direct impact on internal and external governance practices.

Hypothesis 1: Internal governance practices of a nonprofit board are positively and directly impacted by the (a) gender, $(b)$ age, and (c) racial/ethnic diversity of board members.

Hypothesis 2: External governance practices of a nonprofit board are positively and directly impacted by the (a) gender, (b) age, and (c) racial/ethnic diversity of the board members.

\section{Mechanisms Facilitating Board Effectiveness}

Two mechanisms likely enable the ability of diverse board members to effectively undertake governance practices - adoption of specific diversity policies and practices at the board level, and behaviors facilitating inclusion among board members themselves (Bernstein and Bilimoria, 2013; Ely and Thomas, 2001). Board diversity policies and practices, or those procedures that boards adopt with the intent to promote diversity, are commonly believed to enhance diversity and improve the experience for minority group members. These policies and practices frequently include diversity statements, diversity policies, committees or taskforces dedicated to diversity and inclusion, diversity training for board members, and integration of diversity into the organization's core mission and values.

Bradshaw and Fredette (2012) found that boards adopting diversity practices and policies at the board level have more success in recruiting minority board members. Management 
practices such as inclusion of explicit statements allow members to critically reflect on the organization's norms and values so as to facilitate change in their cognitive frames and schemas (Hanappi-Egger, 2012). Many nonprofit organizations, for example, 31\% in New York City (McGill et al., 2009) and 59\% in Michigan (Miller et al., 2009), have formal diversity and/or inclusion policies. One third of respondents in a 2009 BoardSource survey indicated that having such a policy was the second most important route to inclusivity. Based on this empirical evidence, we hypothesize that the effective use of board diversity policies and practices will positively influence a minority board member's experience of inclusion and will positively impact the ability of the board to perform effective internal and external governance practices.

Hypothesis 3: Board diversity policies and practices positively and directly impact (a) internal and (b) external governance practices of a nonprofit board.

A second mechanism, board inclusion behaviors, also likely influences how board diversity enables effective governance practices. Board inclusion behaviors describe actions by board members through which "members of diverse and traditionally marginalized communities are present on boards and meaningfully engaged in the governance of their organization" (Fredette and Bradshaw, 2010, p. 8). Drawing on extant conceptualizations in the literature (Pelled et al., 1999; Mor Barak, 2000; Roberson, 2006; Janssens and Zanoni, 2007), inclusion refers to an individual's or subgroup's sense of efficacy, belonging and value in a work system. Board inclusion behaviors describe the intragroup communication, influence and power interactions that the dominant members of small groups engage in consciously or unconsciously which signal the authentic inclusion of minority members or other members of the non-dominant subgroup. Examples of such behaviors may be whether there exists among board members a consensus about the value and benefits of expanding diversity of the board and a culture that promotes inclusive board dynamics. Such behaviors may be perceived and interpreted by 
minority members as reflecting their true value and treatment by majority members. The experience of inclusion comprises involvement in meaningful groups, access to information and resources necessary for effective job performance, influence in decision-making, and job security (Mor Barak, 2000). The inclusion experienced by minority board members is important because it has consequences for their recruitment, performance and retention, all indicators of successful diversification at the board level.

Organizations that employ an integration and learning motivation perspective for board diversity and focus on encouraging their majority group members to engage in inclusive behaviors, rather than solely on diversity-focused policies and procedures, engendered racial/ethnic minority board members' greater experiences of inclusion (Bernstein and Bilimoria, 2013: Ely and Thomas, 2001). Similarly, Bernstein and Davidson (2012) found that inclusive behaviors mediated the impact of racial/ethnic diversity on governance practices. Thus we hypothesize that:

Hypothesis 4: Board inclusion behaviors positively and directly impact (a) internal and (b) external governance practices of a nonprofit board.

Acknowledging the contradictory results found in the literature examining the impact of diversity on nonprofit governance practices cited above, we hypothesize two mediating factors. Fredette and Bradshaw (2010) suggested that the adoption of functional inclusion ("goal-driven and purposeful inclusion of individuals identified as from diverse or traditionally marginalized communities", p. 8) was more impactful than social inclusion ("embeddedness in the actual social context and fabric of the board of directors, based on authentic relational bonds", p. 10). In fact, without paying attention to the task-oriented activities that are functionally inclusive, social inclusion may not be as impactful. Investigation of the mediation hypotheses enables further understanding of the relationships in nonprofit organizations between board diversity (gender, 
age, and racial/ethnic) and the board's internal and external governance practices. Therefore, to further our understanding of the impact of diversity on governance practices, we hypothesize that board diversity policies and practices, as well as inclusion behaviors, will mediate the impact of board diversity on governance practices.

Hypothesis 5: Board diversity policies and practices mediate the relationship between board (a) gender, $(b)$ age, and (c) racial/ethnic diversity and internal governance practices of a nonprofit board.

Hypothesis 6: Board diversity policies and practices mediate the relationship between board (a) gender, (b) age, and (c) racial/ethnic diversity and external governance practices of a nonprofit board.

Hypothesis 7: Board inclusion behaviors mediate the relationship between board (a) gender, $(b)$ age, and (c) racial/ethnic diversity and internal governance practices of a nonprofit board.

Hypothesis 8: Board inclusion behaviors mediate the relationship between board (a) gender, (b) age, and (c) racial/ethnic diversity and external governance practices of a nonprofit board.

\section{METHODS}

\section{Participants and Procedures}

BoardSource has operated as a resource for nonprofit organizations for more than 25 years with a mission to improve organizational effectiveness by strengthening nonprofit boards (BoardSource, 2012). Member organizations of BoardSource are surveyed biannually using the BoardSource Nonprofit Governance Index (BSGI). This survey includes multiple-choice and open-ended questions to collect chief executive officer (CEO) and board member demographics, organizational characteristics, board structure, diversity and inclusion, board meeting practices, compliance with basic governance roles and responsibilities, and collaborative leadership practices. The survey asks the respondents to rate their board on the performance of 14 competency areas or practices, including strategic thinking, monitoring organizational 
performance, financial oversight, fundraising, and community outreach are assessed by the CEO's (Board Source, 2012). For the current study, we partnered with BoardSource and obtained the raw data from the 2012 CEO survey. From the original dataset we extracted the responses of 1456 chief executive officers from nonprofit organizations whose mission included fundraising. Responses came from all 50 states in the U.S. and included a diverse mix of nonprofit charities, foundations, and associations. Table 1 shows the breakdown of these organizations by annual operating budget and Table 2 details the nonprofit sectors.

Insert Table 1 about here

Insert Table 2 about here

A little more than half of the CEOs of these organizations described themselves as Caucasian women (55\%) with $39 \%$ between 50 and 64 years of age. Two tables detail the demographics of the CEOs, Table 3 shows gender and race while Table 4 includes the age by CEO gender.

Insert Table 3 about here

Insert Table 4 about here 


\section{Measures}

Nine items were used to measure Internal Governance Practices including "Grade your board's performance in understanding your organization's mission" and "Grade your board's performance in understanding the board's roles and responsibilities" with responses $1=$ Fail to 5 = Excellent. Three items were used to measure External Governance Practices including "Grade your board's performance in Fundraising", "Grade your board's performance in community relations and outreach", and Grade your board's performance in recruiting new members" with responses of $1=$ Fail to $5=$ Excellent.

Board diversity policies and practices employed eight items such as "Has your organization incorporated diversity into the organization's core values?" and "Has your organization actively recruited board members from diverse backgrounds?" Board Inclusion Behaviors was measured using 8 items such as "Rate the extent to which board members from diverse backgrounds work together and interact with one another" and "Board members value the contributions of diverse members to the board's tasks" and "Diverse members make contributions to the board's critical tasks". The ratings ranged from $1=$ Not at all to $5=$ To a Great Extent.

Gender Diversity, Age Diversity, and Racial/Ethnic Diversity were measured using Blau's (1977) Index as it is an optimal measure to capture variations within a group (Harrison and Klein, 2007). As a measure of board diversity, the Blau Index meets all four of the following criteria: a zero point to represent complete homogeneity; larger numbers indicate greater diversity; positive values; and frequent use (Miller and Triana, 2009; Harrison and Sin, 2006). A gender diversity index was calculated for each board using the number of board members and number of women board members. A board with no gender diversity would score a 0 and an 
equal gender distributed board would be a 0.5 . The age diversity index was calculated for each board from CEO responses on the number of board members in the following age groups: under 30, 30 to 39,40 to 49,50 to 64 and over 65 . Racial/ethnic diversity was calculated for each board from CEO responses on the number of board members in the following racial/ethnic categories: 1) American-Indian, 2) African American/Black, 3) Asian including Asian Indian, Chinese, Filipino, Japanese, Korean, Vietnamese or other Asian, 4) Caucasian, 5) Hispanic, Latino or Spanish including Mexican American, Chicano, Puerto Rican, Cuban and other Hispanic, 6) Native Hawaiian or Pacific Islander, and 7) Two or more races. A detailed description of the measures used in this study is provided in the Appendix.

\section{Data Analysis}

The 1456 boards were comprised of mostly Caucasian (82\%) members of whom $43 \%$ are women with the age and racial/ethnicity distribution as shown in Table 5 and 6.

Insert Table 5 about here

Insert Table 6 about here

Exploratory factor analysis (EFA) and confirmatory factor analysis (CFA) were employed to verify the uni-dimensionality, validity, and reliability of the model constructs. SPSS for Windows (PASW Statistics Gradpack 17.0, 2009) was used to conduct the EFA. AMOS 17.0.2 was used for the CFA and the structural equation models (SEM). The choice of SEM analysis was made so as to examine a series of dependence relationships simultaneously. SEM is particularly useful in testing theories that contain multiple equations involving dependence relationships using multivariate analysis techniques (Hair Jr., Black, Babin, \& Anderson, 2010). 
The mediation hypotheses were tested using the method recommended by Preacher \& Hayes (2008).

\section{RESULTS}

The effects of board diversity regarding age, race/ethnicity and gender were simultaneously examined to explore the impact on governance practices both internally and externally. A mediation model was hypothesized where board diversity policies and practices in addition to board inclusion behavior were tested as having an impact in developing a structural equation model. Lastly the interaction effects of the diversity factors were tested in terms of their impact on governance practices. The means, standard deviations, reliabilities and correlation between the study variables are shown in Table 7.

Insert Table 7 about here

Several analyses substantiated the validity, uni-dimensionality, and reliability of the measurement models corresponding to the model constructs. Bartlett's test of sphericity was highly significant $(\chi 2=17868 ; \mathrm{df}=171 ; \mathrm{p}<0.000)$ implying that the strength of the relationship among variables is strong. The Kaiser-Meyer-Olkin (KMO) measure of sampling adequacy was 0.927, well above the acceptable level of 0.70 indicating the data was adequate for factoring. The reliability of each construct as measured by Cronbach's $\alpha$ were all above 0.60 (Churchill, 1979) and are detailed in Table 7. The confirmatory factor analysis showed that the model had acceptable fit with $n=1456$ where $\chi^{2}=606, \mathrm{df}=204, \chi^{2} / \mathrm{df}=2.97, \mathrm{CFI}=0.978, \mathrm{RMSEA}=0.037$. Convergent and discriminant validity was established using criteria from Hair et al. (2010).

Additional testing was completed to ensure that there was no bias due to the common method for data collection. A common method bias may be indicated if an examination of the correlation table of the latent variables shows correlation above 0.90 (Pavlou et al., 2007). As 
shown in Table 7, the correlations in this study are all far below 0.90 . Further to assess for methods bias a confirmatory factor analysis was conducted in which the baseline model included a common method factor where each item is linked to this factor (Podsakoff et al., 2003). The variance associated with the measurement model was more than three times greater than the variance associated with the common factor indicating that common method variance does not bias the results of this study.

\section{Direct Effects within the Structural Equation Model}

As shown in Figure 2 hypotheses $\mathrm{H} 1 \mathrm{a}$ and $\mathrm{H} 2 \mathrm{a}$ are supported in the structural equation model as there are positive, direct, significant effects of board gender diversity on both internal $(\beta=.07, \mathrm{p}<0.05)$ and external governance practices $(\beta=.06, \mathrm{p}<0.05)$. There was no support for $\mathrm{H} 1 \mathrm{~b}$ or $\mathrm{H} 2 \mathrm{~b}$ as age diversity was not found to impact these practices, however age diversity was found to impact board diversity policies and practices $(\beta=.08, \mathrm{p}<0.001)$. While we found direct significant effects of racial/ethnic diversity on both internal $(\beta=-.15, \mathrm{p}<0.001)$ and external governance practices $(\beta=-.16, p<0.001)$ hypotheses $\mathrm{H} 1 \mathrm{c}$ and $\mathrm{H} 2 \mathrm{c}$ are not supported as these are negative relationships.

$\mathrm{H} 3 \mathrm{a}$ and $\mathrm{H} 3 \mathrm{~b}$ are supported as board diversity policies and practices directly impact internal governance practices $(\beta=.23, \mathrm{p}<0.001)$ and external governance practices $(\beta=.21, \mathrm{p}<$ 0.001). $\mathrm{H} 4 \mathrm{a}$ and $\mathrm{H} 4 \mathrm{~b}$ are supported as board inclusion behaviors directly impact internal governance practices $(\beta=.27, \mathrm{p}<0.001)$ and external governance practices $(\beta=.26, \mathrm{p}<0.001)$.

Insert Figure 2 about here

\section{Mediation Effects}

The results presented in Table 8 and Figure 2 indicate that board diversity policies and practices partially mediate the relationship between gender diversity and internal governance 
practices as well as between gender diversity and external governance practices, supporting H5a and H6a. Similarly, board diversity policies and practices partially mediate the relationship between racial/ethnic diversity and internal governance practices as well as between racial/ethnic diversity and external governance practices, supporting H5c and H6c. However, no support was found for $\mathrm{H} 5 \mathrm{~b}$ and $\mathrm{H} 6 \mathrm{~b}$ as board diversity policies and practices did not mediate the relationship between board age diversity and internal or external governance practices. Board inclusion behavior partially mediates the relationship between racial/ethnic diversity and internal governance practices as well as between racial/ethnic diversity and external governance practices, supporting H7c and H8c. No support was found for board inclusion behavior partially mediating the relationship between gender diversity and internal or external governance practices ( $\mathrm{H} 7 \mathrm{a}$ and $\mathrm{H} 8 \mathrm{a})$ or between age diversity and internal or external governance practices ( $\mathrm{H} 7 \mathrm{~b}$ and $\mathrm{H} 8 \mathrm{~b})$.

Table 8 includes the direct, indirect and total effects for gender, age and racial/ethnic diversity on board inclusive behaviors, and internal and external governance practices. This table shows that as a mediator board inclusion behavior links board diversity policies and practices to governance practices. Board inclusion behaviors explain how diversity policies and practices impact governance practices. Further, the mediation testing shows that board inclusion behaviors are the mechanism through which gender and racial/ethnic diversity impact board policies and procedures.

Insert Table 8 about here 


\section{Interaction Effect}

While not hypothesized, we examined the interaction effects of board diversity on internal and external governance practices. We found that the board's external governance practices are impacted by an interaction between gender and racial/ethnic diversity (see Figure 3). As detailed earlier there is an inverse relationship between racial/ethnic diversity and external governance practices, where more racial/ethnic diversity results in less effective external governance practices. However the level of gender diversity was found to moderate the impact of racial/ethnic diversity on the effectiveness of external governance practices such that when there is greater gender diversity it dampens the inverse relationship between racial diversity and external board practices. The most interesting aspect of this analysis is that racial/ethnic diversity becomes a positive influence on external governance practices when there is greater gender diversity. This finding suggests that board diversity dimensions have complex effects on board performance factors.

Insert Figure 3 about here

\section{DISCUSSION}

The present study of nonprofit boards reveals four important findings describing how and when board diversity impacts governance practices. First, the study supports previous work in the for-profit and nonprofit sectors that a board's diversity impacts the effective performance of its governance duties and responsibilities. Second, a board's diversity policies and practices as well as its inclusion behaviors impact the effectiveness of its governance practices. Third, board diversity aspects of gender, age and race/ethnicity impact its diversity policies and practices. These diversity policies and practices are the mechanisms through which board diversity impacts 
internal and external governance practices. Lastly, the relationship between governance practices and the racial/ethnic diversity of the board is complex as it is impacted by board diversity policies and practices, the inclusive behaviors of the board and also an interaction effect related to the gender diversity of the board. Not only do these findings add to the literature on boards and diversity, but these findings can be used by nonprofit CEOs and board directors to more effectively leverage board diversity to influence governance practices thereby fulfilling the mission of the organization.

The first main finding is that board diversity impacts governance practices but that this impact is manifested differently for gender, age and racial/ethnic diversity. The results showed that gender diversity on nonprofit boards not only impacts board internal and external governance practices but also impacts the policies and practices of the board related to diversity and inclusion. Simply stated, a board that has greater gender diversity has more effective governance practices and is more likely to have policies and practices related to diversity. This is an important finding because many question the value of diversity and the findings offer clear evidence that greater gender diversity leads to more effective performance of internal and external governance practices. The finding that gender diversity directly impacts governance practices is consistent with studies of for-profit boards which have concluded that gender diversity significantly impacts board and firm performance (e.g., Boulouta, 2013; Campbell and Mínguez-Vera, 2008; Carter et al., 2003; Erhart et al., 2003; Francoeur et al, 2008; Hafsi \& Turgut, 2013; Zhang et al, 2013).

The age diversity of the nonprofit boards in this study was skewed toward an older population and this variable significantly impacted only the board's diversity policies and practices. This finding is consistent with the propensity for organizations to adopt normative 
diversity policies and practices in the later $20^{\text {th }}$ century. An explanation of this finding may be that older board members feel more comfortable focusing on diversity policies and practices that have been in place for a while. Today workplace diversity has evolved from meeting quotas dictated by federal law to the current focus on fostering inclusion and achieving maximum success. Many organizations use diversity policies and practices as only a part of an encompassing culture of diversity which expects and fosters inclusive behaviors (Anand and Winters, 2008).

The second main finding indicates that policies and practices related to diversity positively impact governance practices in nonprofit organizations. The development of these diversity policies and practices is influenced by the diversity of the board, and the greater the diversity (gender, age and racial/ethnic) the more there are diversity-related policies and practices. Additionally, behaviors related to including board members directly impact the performance of both internal and external governance practices. These board inclusion behaviors are influenced by the diversity policies and practices within the board. The behaviors related to inclusion also are influenced by racial/ethnic diversity. Board diversity policies and practices partially mediate the impact of racial/ethnic diversity on board inclusion behaviors.

A third key contribution of this study is support for the adoption of board diversity policies and practices as a mechanism that enables board diversity to influence governance practices. Board diversity policies and practices provide the foundation, setting up the minimum standards to include diverse members. These policies and practices articulate the values of the board and establish a common language that is used to overcome visible differences between board members. As boards establish more policies and practices related to diversity $\mathrm{n}$ there will 
likely continue to be improvements in the effective performance of internal and external governance practices.

Understanding the dynamics involved with the racial/ethnic diversity of the boards involves a series of small steps. First it is important to understand the distribution of race/ethnicity within the study's sample as these boards comprised of mostly Caucasians (82\%) with almost 9\% African-American/Black, 4\% Hispanic and 3\% Asian as detailed in Table 3. Next, looking at the direct relationship between racial/ethnic diversity and the performance of governance practices, both internal and external, it is an inverse relationship such that more racial/ethnic diversity means less performance of these effective governance practices. These findings, while consistent with previous nonprofit studies (Bernstein and Davidson, 2012) are inconsistent with Carter et al. (2003) and Erhart et al.'s (2003) determination that racial diversity has been shown to positively influence for-profit firm performance. However within the multivariate data analysis, the presence of diversity and diversity policies and practices together with inclusion behaviors by the board creates a positive influence shifting the overall impact of racial/ethnic diversity on governance practices to a positive overall influence (see Table 8 ). The mechanism for positively influencing governance practices with racial/ethnic diversity is to have diversity policies and practices in place along with inclusion behaviors. The evidence presented here suggests that in the absence of diversity policies and practices and/or inclusion behaviors, greater racial/ethnic diversity will likely result in less effective governance practices.

A fourth important finding from this study is that effective external governance practices were influenced by an interaction effect between racial/ethnic diversity and gender diversity. Because the direct impact of racial/ethnic diversity on effective governance practices is an inverse relationship, having more gender diversity, regardless of the level of board diversity 
policies and practices or inclusion behavior, will serve to mitigate the direct effect. Boards that are more diverse in race/ethnicity will have more effective governance practices when the gender diversity is higher.

The relevant literature has been reviewed and well-documented methods have been employed to obtain the findings, however several limitations to this study should be noted. The data used to develop the model was reported only by each nonprofit organization's CEO. A rigorous methodological approach of theory testing has been adopted that seems to confirm the adequacy of the structural equation model but it is possible that other dimensions impacting board performance have not been included. The separation of the constructs related to internal and external governance practices may also be a limitation. The model shows subtle differences in the factors that impact these dependent variables however adequate validity and reliability was established in the exploratory and confirmatory factor analyses. Finally, the study used data collected by BoardSource from its members who are nonprofit organizations' chief executive officers. A study of random nonprofit organizations may yield different insights. Despite these limitations, this study provides a rigorous quantitative examination of board diversity and performance in the nonprofit sector.

\section{Future Research}

The use of the 2012 BoardSource Governance Index (BSGI) Survey for Chief Executives highlights the value of using surveys of organizations to investigate important issues and theories for the nonprofit sector. Similarly, secondary analyses of these surveys can lead to improvements in subsequent surveys, yielding valuable findings and insights for nonprofit leaders and researchers. The examination of previous and future BoardSource Governance Indices is recommended as the survey data is rich and analyses can add to deeper and broader 
understanding of how nonprofit boards function. We also suggest that further work be done to determine additional factors, including mediators and moderators, that impact effective governance practices. Finally we recommend that future studies examine the relationships presently studied in sectors other than nonprofit boards.

\section{Implications for Practice}

From a practical standpoint, this study shows how research can be used by leaders to benefit their organization's ability to attain its mission. Boards seeking to improve their governance effectiveness should include diverse board members, but must be certain that there are diversity policies and practices in place to allow the diverse members to have a positive impact. Inclusion behaviors and an inclusive culture have an impact on the ability of diverse members to positively impact the board, especially when there is greater racial/ethnic diversity. The findings indicate that boards with more gender and racial/ethnic diversity will have more effective governance practices than those with less diversity; thus board chairs and nominating committees should seek both gender and racial/ethnic diversity when recruiting new members. When diverse board members are encouraged to participate fully through meaningful diversity policies and practices as well as inclusive behaviors among members, board diversity positively impacts board performance. 


\section{References}

Anand, R. and Winters, M.F. (2008). A retrospective view of corporate diversity training from 1964 to the present. Academy of Management Learning \& Education 7 (3), 356-372.

Alliance for Board Diversity. (2013). Missing Pieces: Women and Minorities on Fortune 500 Boards. Retrieved from http://theabd.org/2012_ABD\%20Missing_Pieces_Final_8_15_13.pdf

Bernstein, R. S. and Bilimoria, D. (2013). Diversity perspectives and minority nonprofit board member inclusion. Equality, Diversity and Inclusion: An International Journal 32(7), 636-653.

Bernstein, R. S. and Davidson, D. (2012). Exploring the link between diversity, inclusive practices, and board performance: An analysis of the national BoardSource Nonprofit Governance Index. In annual conference of the Association for Research on Nonprofit Organizations and Voluntary Action, Washington, DC.

Bilimoria, Diana (2000). Building the Business Case for Women Corporate Directors, in Burke, Ronald J. and Mattis, Mary C. (Eds.), Women on Corporate Boards of Directors: International Challenges and Opportunities, Dordrecht, The Netherlands: Kluwer Academic Publishers, pp. $25-40$.

Bilimoria, Diana (2006). The Relationship between Women Corporate Directors and Women Corporate Officers, Journal of Managerial Issues, 18(1), 47-61.

Blau, P. (1977). Heterogeneity and inequality: Towards a primitive theory of social structure. Free Press, New York, NY.

BoardSource. (2012). BoardSource Nonprofit Governance Index. Retrieved from CEO Survey of Board Source Members:

https://www.boardsource.org/eweb/Dynamicpage.aspx?webkey=8fac70bd-ea31-4c89-91bf$\underline{\mathrm{e} 3 \mathrm{a} 7 \mathrm{~d} 3 \mathrm{e} 705 \mathrm{cc}}$

Boulouta, I. (2013). Hidden Connections: The Link between Board Gender Diversity and Corporate Social Performance. Journal of Business Ethics 113, 185-197.

Bradshaw, P., and Fredette, C. (2011). The inclusive nonprofit boardroom: Leveraging the transformative potential of diversity. Nonprofit Quarterly Spring, 21-26.

Bradshaw, P. and Fredette, C. (2012). Determinants of the Range of Ethnocultural Diversity on Nonprofit Boards: A Study of Large Canadian Nonprofit Organizations. Nonprofit and Voluntary Sector Quarterly. Doi:10.1177/0899764012453085

Bradshaw, P., Murray, V. and Wolpin, J. (1992). Do nonprofit boards make a difference? An exploration of the relationships among board structure, process, and effectiveness. Nonprofit and Voluntary Sector Quarterly 21(3), 227-249. 
Bradshaw, P., Murray, V. and Wolpin, J. (1996). Women on boards on nonprofits: What difference do they make? Nonprofit and Voluntary Sector Quarterly 6, 241-254.

Brown, W. A. (2002). Inclusive governance practices in nonprofit organizations and implications for practice. Nonprofit Management \& Leadership 12(4), 369-385.

Callen, J. L., Klein, A. and Tinkelman, D. (2010). The contextual impact of nonprofit board composition and structure on organizational performance: Agency and resource dependence perspectives. Voluntas: International Journal of Voluntary and Nonprofit Organizations 21(1), 101-125.

Campbell, K. and Mínguez-Vera, A. (2008). Gender diversity in the boardroom and firm financial performance. Journal of Business Ethics 83(3), 435-451.

Carter, D. A., Simkins, B. J. and Simpson, W. G. (2003). Corporate governance, board diversity, and firm value. Financial Review 38(1), 33-53.

Chait, R. P., Holland, T. P. and Taylor, B. E. (1991). The effective board of trustees. Macmillan, New York, NY.

Churchill, J. G. (1979). A Paradigm for Developing Better Measures of Marketing Constructs. Journal of Marketing Research XVI, 64-73.

Cornforth, C. (2001). What makes boards effective? An examination of the relationships between board inputs, structures, processes and effectiveness in non-profit organizations. Corporate Governance: An International Review 9(3), 217-227.

Cornforth, C. (2012). Challenges and future direction for nonprofit governance research. Nonprofit and Voluntary Sector Quarterly 41(6), 1117-1136.

Cox, T. H., Lobel, S. A. and McLeod, P. L. (1991). Effects of ethnic group cultural differences on cooperative and competitive behavior on a group task. Academy of Management Journal 34, 827-847.

Duca, D. J. (1996). Nonprofit boards: Roles, responsibilities, and performance. Wiley, New York, NY.

Ely, R. J. and Thomas, D. A. (2001). Cultural diversity at work: The effects of diversity perspectives on work group process and outcomes. Administrative Science Quarterly 46, 229273.

Erhardt, N. L., Werbel, J. D. and Sharder, C. B. (2003). Board of director diversity and firm financial performance. Corporate Governance 11, 102-11.

Francoeur, C., Labelle, R., and Sinclair-Desgagné, B. (2008). Gender diversity in corporate governance and top management. Journal of Business Ethics, 81(1), 83-95. 
Fredette, C. and Bradshaw, P. (2010). From diversity to inclusion: A multi-method examination of diverse governing groups. In annual conference of the Association for Research on Nonprofit Organizations and Voluntary Action, Washington, DC.

Ferreira, D. (2010). Board diversity." In Baker, H. \& Anderson, R. (Eds.), Corporate Governance: A synthesis of theory, research, and practice, (pp. 225-241). John Wiley \& Sons, New York, NY.

Gitin, M. (2001). Beyond representation: Building diverse board leadership teams. New Directions for Philanthropic Fundraising 34, 77-100.

Green, J. C. and Griesinger, D. W. (1996). Board performance and organizational effectiveness in nonprofit social services organizations. Nonprofit Management and Leadership 6(4), 381-402.

Hafsi, T. and Turgut, G. (2013). Boardroom diversity and its effect of social performance: Conceptualization and empirical evidence. Journal of Business Ethics. 112(3), 463-479.

Hair Jr., J. F., Black, W. C., Babin, B. J., \& Anderson, R. E. (2010). Multivariate Data Analysis 7th Edition. Upper Saddle River: Pearson Education Inc.

Hanappi-Egger, E. (2012). 'Shall I stay or shall I go"? On the role of diversity management for women's retention in SET professions'. Equality, Diversity and Inclusion: An International Journal 31(2), 144-157.

Harrison, D. A. and Klein, K. J. (2007). What's the difference? Diversity constructs as separation, variety and disparity in organization. Academy of Management Review 32, 11991228.

Harrison, D. A. and Sin, H.-P. (2006). What is diversity and how should it be measured? In Konrad, A. M., Prasad, P. \& Pringle, J. K. (Eds), Handbook of Workplace Diversity, (pp. 191216.). Sage, London.

Herman, R. D. and Renz, D. O. (1998). Nonprofit organizational effectiveness: Contrasts between especially effective and less effective organizations. Nonprofit Management and Leadership 9(1), 23-38.

Herman, R. D., Renz, D. O. and Heimovics, R. D. (1996). Board practices and board effectiveness in local nonprofit organizations. Nonprofit Management and Leadership 7(4), 373385.

Horwitz, S. K. and Horwitz, I. B. (2007). The effects of team diversity on team outcomes: A meta-analytic review of team demography. Journal of Management 33(6), 987-1015.

Jackson, D. K. and Holland, T. P. (1998). Measuring the effectiveness of nonprofit boards. Nonprofit and Voluntary Sector Quarterly 27(2), 159-182. 
Jackson, S. E., May, K. A. and Whitney, K. (1995). Understanding the dynamics of diversity in decision making teams. In R. A. Guzzo and E. Salas (Eds.), Team decision making effectiveness in organizations (pp. 204-261). Jossey-Bass, San Francisco, CA.

Janssens, M. and Zanoni, P. (2007). What makes an organization inclusive? Work context and diversity management practices favoring ethnic minorities' inclusion'. Paper presented at the Academy of Management conference, Philadelphia, PA.

Jehn, K. A. and Bezrukova, K. (2004). A field study of group diversity, workgroup context, and performance. Journal of Organizational Behavior 25, 703-729.

Jehn, K. A., Northcraft, G. B. and Neale, M. A. (1999). Why differences make a difference: A field study of diversity, conflict, and performance in workgroups. Administrative Science Quarterly 44(4), 741-763.

Joshi, A. \& Roh, H. (2009). The role of context in work team diversity research: A meta-analytic review. Academy of Management Journal 52(3), 599-627.

Kochan, T., Bezrukova, K., Ely, R., Jackson, S., Joshi, A., Jehn, K., Leonard, J., Levin, D. and Thomas, D. (2003). The effects of diversity on business performance: Report of the diversity research network. Human Resource Management 42(1), 3-21.

McGill, L., Bryan, B. and Miller, E. (2009). Benchmarking diversity: A first look at New York City foundations and nonprofits, Foundation Center.

Miller, K. P., Brewer, M. B. and Arbuckle, N. L. (2009). Social identity complexity: Its correlates and antecedents'. Group Processes and Intergroup Relations 12(1), 79-94.

Miller T. and Triana, M. (2009). Demographic diversity in the boardroom: Mediators of the board diversity-firm performance relationship. Journal of Management Studies 46(5), 755-786.

Milliken, F. J. and Martins, L. L. (1996). Searching for common threads: Understanding the multiple effects of diversity in organizational groups. Academy of Management Review, 21(2), 402-433.

Mor Barak, M. E. (2000). Beyond affirmative action: Toward a model of diversity and organizational Inclusion. Administration in Social Work, 23, 47-68.

Nobbie, P. D. and Brudney, J. L. (2003). Testing the implementation, board performance, and organizational effectiveness of the policy governance model in nonprofit boards of directors. Nonprofit and Voluntary Sector Quarterly 32(4), 571-595.

Pavlou, P., Liang, H., \& Xue, Y. (2007, March). Understanding and Mitigating Undertainty in OnLine Exchange Relationships: A Principal-Agent Perspective. MIS Quarterly, 31(1), 105-136. 
Pelled, L. H., Ledford, G. E. and Mohrman, S. A. (1999). Demographic disparity and workplace inclusion. Journal of Management Studies, 36(7), 1013-1031.

Pitts, D. W. (2006). Modeling the impact of diversity management. Review of Public Personnel Administration 26(3), 245-268.

Podsakoff, P. M., MacKenzie, S. B., Lee, J.-Y., \& Podsakoff, N. (2003). Common Method Bias in Behavioral Research: A Critical Review of the Literature and Recommended Remedies. Journal of Applied Psychology, 5, 879-903.

Preacher, K. J., \& Hayes, A. F. (2008). Asymptotic and Resampling Strategies for Assessing and Comparing Indirect Effects in Multiple Mediator Models. Behavior Research Methods, 40(3), 879-891.

Roberson, Q. M. (2006). Disentangling the meanings of diversity and inclusion in organizations. Group and Organization Management 31, 212-236.

Siciliano, J.I. (1996). The relationship of board member diversity to organizational performance. Journal of Business Ethics 15, 1313-1320.

Stone, M. M. and Ostrower, F. (2007). Acting in the public interest? Another look at research on nonprofit governance. Nonprofit and Voluntary Sector Quarterly 36, 416-438.

Treuhaft, S., Blackwell, A. G. and Pastor, M. (2011). America's tomorrow: Equity is the superior growth model. Policy Link. Prepared with the University of Southern California's Program for Environmental and Regional Equity.

Ugboro, I. O. and Obeng, K. (2009). Board activities, involvement, and public transit performance. Administration and Society 41(2), 235-257.

van Knippenberg, D. and Schippers, M. C. (2007). Work group diversity. Annual Review of Psychology 58, 515-541.

Williams, K. Y. and O'Reilly, C. A. (1998). Demography and diversity in organizations: A review of 40 years of research. Research in Organizational Behavior, 20, 77-140.

Zhang, J., Zhu, H., and Ding, H. (2013). Board composition and corporate social responsibility: An empirical investigation in the post Sarbanes-Oxley era. Journal of Business Ethics. 114(3), 381-392. 
Table 1

Organizations’ Annual Operating Budget

\begin{tabular}{lcc}
\hline $\begin{array}{c}\text { Annual Operating } \\
\text { Budget }\end{array}$ & $\begin{array}{c}\text { Number of } \\
\text { Organizations }\end{array}$ & Percent \\
\hline Under $\$ 250,000$ & 82 & $5.6 \%$ \\
\$250-\$499,000 & 164 & $11.3 \%$ \\
\$500-\$999,000 & 223 & $15.3 \%$ \\
\$1-4.9 million & 517 & $35.5 \%$ \\
\$5-\$9.9 million & 184 & $12.6 \%$ \\
\$10-24.9 million & 172 & $11.8 \%$ \\
\$25 million or more & 114 & $7.8 \%$ \\
Total & $\mathbf{1 4 5 6}$ & $\mathbf{1 0 0 . 0}$ \\
\hline
\end{tabular}

Table 2

Type of Nonprofit Organizations

\begin{tabular}{lcc}
\hline Type of Nonprofit & $\begin{array}{c}\text { Number of } \\
\text { Organizations }\end{array}$ & Percent \\
\hline Arts and culture & 104 & 7.1 \\
Business/industry & 35 & 2.4 \\
Community/economic development & 55 & 3.8 \\
School/college/university & 136 & 9.3 \\
Environment & 44 & 3.0 \\
Health care & 220 & 15.1 \\
Housing and shelter & 92 & 6.3 \\
Human/social services & 424 & 29.1 \\
International development & 15 & 1.0 \\
Philanthropy/grant making & 111 & 7.6 \\
Religious congregation & 13 & .9 \\
Science and technology & 11 & .8 \\
Sports and recreation & 22 & 1.5 \\
Youth development & 88 & 6.0 \\
Other & 81 & 5.6 \\
Total & 1451 & 99.7 \\
Missing & 5 & 0.3 \\
\hline
\end{tabular}


Table 3

CEO Respondents - Gender and Race

\begin{tabular}{lccc}
\hline CEO Race & Female & Male & Total \\
\hline Caucasian & 806 & 530 & 1336 \\
African American/Black & 34 & 20 & 54 \\
Hispanic, Latino or Spanish & 22 & 7 & 29 \\
Two or more races & 11 & 2 & 13 \\
Asian & 6 & 2 & 8 \\
American Indian/Alaskan & 2 & 3 & 5 \\
Native Hawaiian/Pacific Islander & 1 & 0 & 1 \\
Race Missing & 7 & 3 & 10 \\
Total & 889 & 567 & 1456 \\
\hline
\end{tabular}

Table 4

CEO Respondents - Gender and Age

\begin{tabular}{lccc}
\hline CEO Age Range in Years & Female & Male & Total \\
\hline Under 40 & 55 & 31 & 86 \\
40 to 49 & 178 & 113 & 291 \\
50 to 64 & 567 & 343 & 910 \\
65 and Older & 88 & 79 & 167 \\
Age Missing & 1 & 1 & 2 \\
Total & 889 & 567 & 1456 \\
\hline
\end{tabular}

Table 5

Board Race/Ethnicity Distribution as Reported by CEOs

\begin{tabular}{lc}
\hline Board Member Race/Ethnicity & \\
\hline American Indian or Alaska Native & $0.7 \%$ \\
African American/Black & $8.5 \%$ \\
Asian (includes Asian Indian, Chinese, Filipino, Japanese, & $3.0 \%$ \\
Korean, Vietnamese, or other Asian) & \\
Caucasian & $82.4 \%$ \\
Hispanic, Latino, or Spanish (includes Mexican, Mexican & $4.3 \%$ \\
American, Chicano, Puerto Rican, Cuban, and other & \\
Hispanic, Latin, or Spanish origins) & $0.2 \%$ \\
Native Hawaiian or Pacific Islander & $0.9 \%$ \\
\hline
\end{tabular}


Table 6

Board Age Distribution as Reported by CEOs

\begin{tabular}{lr}
\hline Board Members Age Range & \\
\hline Under 30 & $.1 \%$ \\
30 to 39 years & $11.5 \%$ \\
40 to 49 years & $27.7 \%$ \\
50 to 64 years & $42.7 \%$ \\
65 years or older & $15.9 \%$ \\
\hline
\end{tabular}

Table 7

Means, Standard Deviations, Cronbach's Alphas and Correlations for Board Source Data

\begin{tabular}{|c|c|c|c|c|c|c|c|c|}
\hline & Mean & SD & 1 & 2 & 3 & 4 & 5 & 6 \\
\hline $\begin{array}{l}\text { 1. Internal Governance } \\
\text { Practices }\end{array}$ & 2.91 & .684 & .882 & & & & & \\
\hline $\begin{array}{l}\text { 2. External Governance } \\
\text { Practices }\end{array}$ & 2.02 & .840 & .734 & .794 & & & & \\
\hline $\begin{array}{l}\text { 3. Board Inclusion } \\
\text { Behaviors }\end{array}$ & 3.02 & .790 & .284 & .266 & .944 & & & \\
\hline $\begin{array}{l}\text { 4. Board Diversity } \\
\text { Policies \& Practices }\end{array}$ & 4.16 & 2.02 & .285 & .256 & .361 & & & \\
\hline 5. Age Diversity & .500 & .167 & .011 & .060 & .110 & .105 & & \\
\hline 6. Race/Ethnic Diversity & .221 & .194 & .059 & .041 & .474 & .334 & .166 & \\
\hline 7. Gender Diversity & .407 & .121 & .091 & .079 & .062 & .076 & .030 & .070 \\
\hline
\end{tabular}




\section{Table 8}

Direct, Indirect and Total Effects of Variables on Board Inclusion Behaviors, Internal and External Governance Practices

\begin{tabular}{|c|c|c|c|c|c|c|c|c|c|}
\hline & \multicolumn{3}{|c|}{ Board Inclusion Behaviors } & \multicolumn{3}{|c|}{ Internal Governance Practices } & \multicolumn{3}{|c|}{ External Governance Practices } \\
\hline & Direct & Indirect & Total & Direct & Indirect & Total & Direct & Indirect & Total \\
\hline $\begin{array}{l}\text { Gender } \\
\text { Diversity }\end{array}$ & & & & $.067 *$ & .012 & $.079^{*}$ & $.063^{*}$ & .011 & $.074 *$ \\
\hline $\begin{array}{c}\text { Age } \\
\text { Diversity }\end{array}$ & & & & & .024 & .024 & & .023 & .023 \\
\hline $\begin{array}{c}\text { Race/Ethni } \\
\text { Diversity }\end{array}$ & $.397 * * *$ & $.073 *$ & $.471 * * *$ & $-.151 * * *$ & $.202 * *$ & $.051^{*}$ & $-.161 * * *$ & $.193^{* * *}$ & $.032 *$ \\
\hline $\begin{array}{c}\text { Diversity } \\
\text { Policies \& } \\
\text { Practices }\end{array}$ & & & & $.233 * * *$ & $.062^{*}$ & $.295^{* * *}$ & $.214 * * *$ & $.060^{*}$ & $.275^{* * *}$ \\
\hline $\begin{array}{l}\text { Inclusion } \\
\text { Behaviors }\end{array}$ & & & & $.269 * * *$ & & $.269^{* * *}$ & $.264 * * *$ & & $.264 * * *$ \\
\hline
\end{tabular}

$* \mathrm{p}<.05, * * \mathrm{p}<.01, * * * \mathrm{p}<.001$

Figure 1.

Hypothesized Model

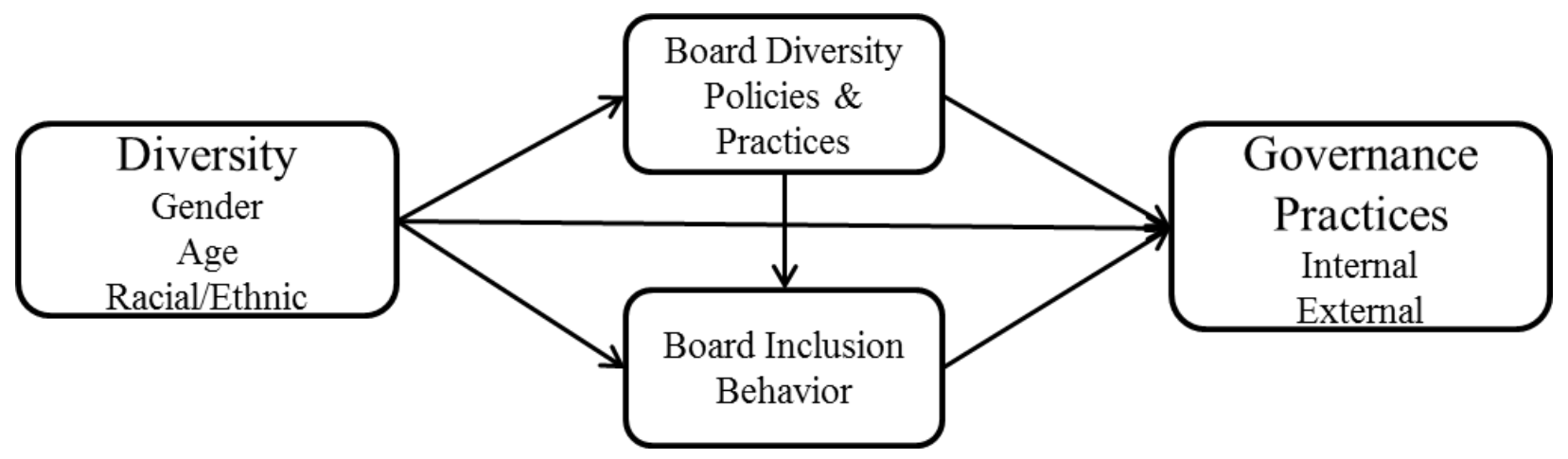


Figure 2.

Standardized Solution for Internal and External Board Governance Practices

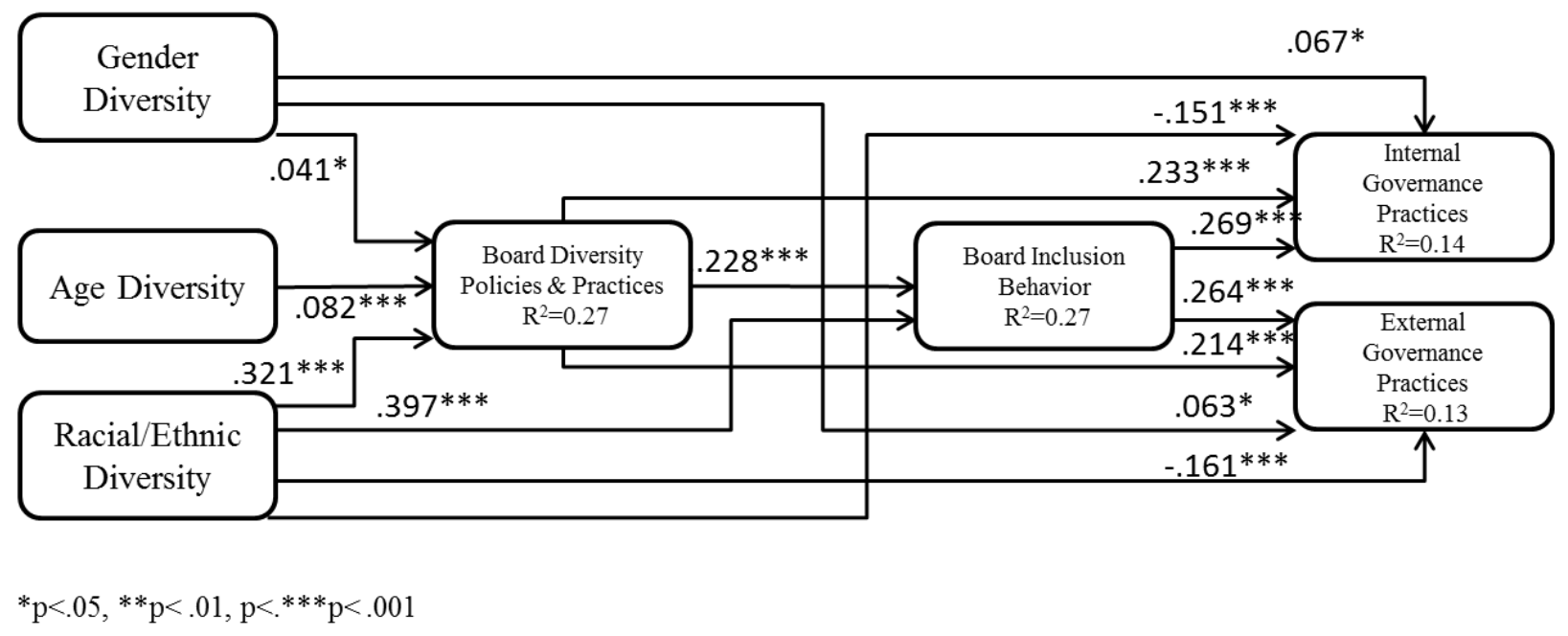


Figure 3. Interaction Effect of Gender and Race on External Governance Practices

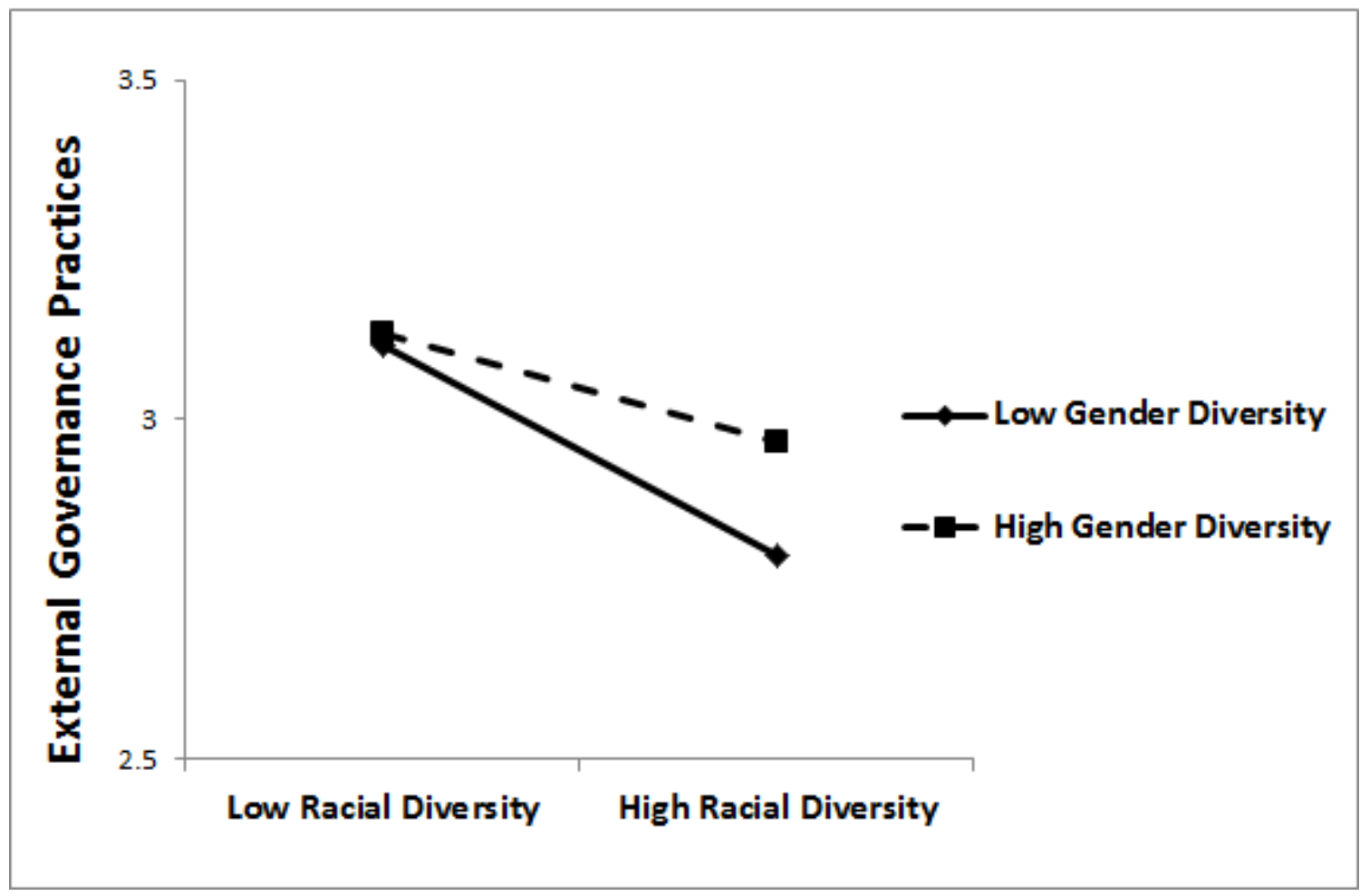


Appendix: Study Measures

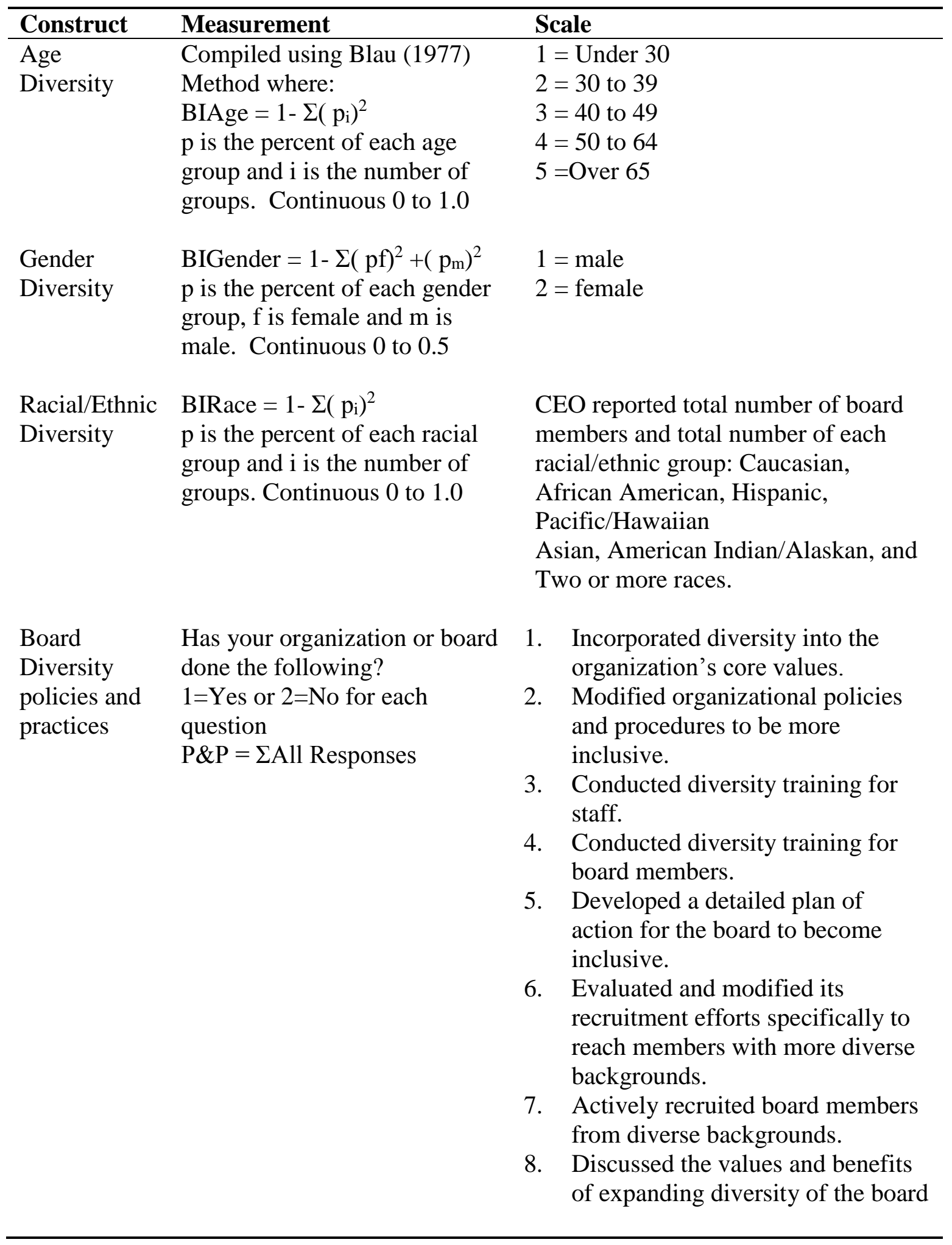




\begin{tabular}{|c|c|c|}
\hline $\begin{array}{l}\text { Board } \\
\text { Inclusion } \\
\text { Behavior }\end{array}$ & $\begin{array}{l}\text { Please rate the extent to which } \\
\text { board members from diverse } \\
\text { backgrounds work together and } \\
\text { interact with one another. } \\
1=\text { Not at all } \\
5=\text { Great Extent }\end{array}$ & $\begin{array}{l}\text { 1. Board members initiate social } \\
\text { interactions with members' from } \\
\text { diverse backgrounds. } \\
\text { 2. Board members value the } \\
\text { contributions of diverse members to } \\
\text { the board's tasks } \\
\text { 3. Diverse members participate in } \\
\text { developing the board's most } \\
\text { important policies } \\
\text { 4. Members take a personal interest in } \\
\text { board members from diverse } \\
\text { backgrounds } \\
\text { 5. Diverse members make } \\
\text { contributions to the board's critical } \\
\text { tasks. } \\
\text { 6. Diverse members become friends } \\
\text { with the other members of the } \\
\text { board. } \\
\text { 7. Diverse members are influential in } \\
\text { the board's routine activities. } \\
\text { 8. Diverse members share their } \\
\text { personal ideas, feelings, and hopes } \\
\text { with other members of the board. }\end{array}$ \\
\hline $\begin{array}{l}\text { Internal } \\
\text { Governance } \\
\text { Practices }\end{array}$ & $\begin{array}{l}\text { Grade your board's } \\
\text { performance in the following } \\
\text { areas. } \\
1=\text { Fail } \\
5=\text { Excellent }\end{array}$ & $\begin{array}{l}\text { 1. Understanding your organization's } \\
\text { mission } \\
\text { 2. Strategic planning and thinking } \\
\text { strategically. } \\
\text { 3. Knowledge of your organizations } \\
\text { programs } \\
\text { 4. Monitoring organizational } \\
\text { performance and impact } \\
\text { 5. Legal and ethical oversight } \\
\text { 6. Financial oversight } \\
\text { 7. Evaluating the chief executive } \\
\text { 8. Providing guidance and support to } \\
\text { the chief executive } \\
\text { 9. Understanding the board's roles and } \\
\text { responsibilities }\end{array}$ \\
\hline $\begin{array}{l}\text { External } \\
\text { Governance } \\
\text { Practices }\end{array}$ & $\begin{array}{l}\text { Grade your board's } \\
\text { performance in the following } \\
\text { areas. } \\
1=\text { Fail } \\
5=\text { Excellent }\end{array}$ & $\begin{array}{l}\text { 1. Fundraising } \\
\text { 2. Community relations and outreach } \\
\text { 3. Recruiting new board members }\end{array}$ \\
\hline
\end{tabular}


Influence of Diversity on Board Practices 